\title{
Knowledge, Attitudes and Practices Related to Antibiotic Use Among Community and Hospital Pharmacists in Galle District, Sri Lanka
}

\author{
Meenu Amarasinghe ${ }^{1}$, Ha Nguyen Viet ${ }^{2}$, Shukry Zawahir ${ }^{3, *}$ \\ ${ }^{1}$ Faculty of Medicine, University of Ruhuna, Galle, Sri Lanka. \\ ${ }^{2}$ Woolcock Institute of Medical Research Vietnam, Vietnam. \\ ${ }^{3}$ Central Clinical School, Faculty of Medicine and Health, The University of Sydney, NSW, Australia.
}

Received: 19 Feb 2021;

Accepted: 15 April 2021

*Correspondence to:

Dr. Shukry Zawahir,

Postdoctoral Research Associate, Central

Clinical School, Faculty of Medicine and Health,

The University of Sydney, NSW, AUSTRALIA.

Email: shukry2010@gmail.com

Copyright: (c) the author(s),publisher and licensee Indian Academy of Pharmacists. This is an open-access article distributed under the terms of the Creative Commons Attribution Non-Commercial License, which permits unrestricted non-commercial use, distribution, and reproduction in any medium, provided the original work is properly cited.

\begin{abstract}
Background: Pharmacists' knowledge about and attitudes towards antibiotic impact on appropriate antibiotic supply. However, this information is lacking in Sri Lanka. Purpose: To evaluate the knowledge, attitudes and practice of antibiotic use and antibiotic resistance (AR) among community pharmacists and hospital pharmacists in Galle District, Sri Lanka. Methods: A cross-sectional study using a self-administered questionnaire was conducted to assess their knowledge about antibiotic use and causes of $A R$, attitudes towards antibiotic use and dispensing practice. Data were analyzed using descriptive and inferential statistics. Results: Ninety percent of the pharmacists $(n=90 / 100)$ responded, comprising community pharmacists ( $n=43$ ) with efficiency qualifications and hospital pharmacists with proficiency $(n=45)$ or B.Pharm $(n=2)$ qualifications. The hospital pharmacists' knowledge about consequences of inappropriate antibiotic use, ineffective treatment $(100 \%)$ and AR $(100 \%)$, were significantly higher than community pharmacists' knowledge $(91 \%$ and $86 \% ; P=0.048$ and 0.010 , respectively). The knowledge about AR reasons, for example, antibiotic use for non-bacterial infections, was also significantly higher in hospital pharmacists (92\%) than community pharmacists $(74 \%), P=0.030$. $84 \%$ of respondents had positive responses on all attitude statements. Most of the participants (98\%) denied non-prescription antibiotic supply. Overall, greater knowledge about antibiotic use increased the likelihood of higher knowledge about AR (Adj. $\mathrm{OR}=3.94 ; 95 \% \mathrm{Cl}$ : 1.57-9.88; $P=0.003$ ) and positive attitude towards it (Adj. $\mathrm{OR}=3.71 ; 95 \% \mathrm{Cl}$ : 1.54-8.92; $P=0.003)$. Conclusion: Extent of pharmacy qualification could impact the pharmacists' antibiotic use and AR knowledge. Raising pharmacists' knowledge about antibiotic use may enhance their AR knowledge and attitudes towards it.
\end{abstract}

Key words: Antibiotics, Knowledge, Attitudes, Practices, Sri Lanka, Community Pharmacists.

\section{INTRODUCTION}

An infection was considered serious and life-threatening until the discovery of antibiotics which have saved countless lives. However, in recent decades, the emergence and spread of antibiotic-resistant bacteria, especially multidrugresistant strains, which causes a significant threat to global health, is a major growing concern. ${ }^{[1]}$ Antibiotic resistance (AR) crisis is more problematic in low and middle-income countries (LMICs) including Sri Lanka where infectious diseases is a high burden. ${ }^{[2]} \mathrm{AR}$ was proved to be a healthcare concern in Sri Lanka by the high prevalance of resistant trains of Escherichia coli and Streptococcus pneumoniae found in patient isolates. ${ }^{[3,4]}$ The increase of AR will result in failure of therapeutic effectiveness, leading to longer and more severe illness episodes with higher costs, mortality and morbidity rates. ${ }^{[5,6]}$

The emergence of resistant microorganisms is a natural biological adaptation, it is exacerbated by the inappropriate use of antibiotics (e.g. inappropriate medication and dose, shorter than required duration, or treatment of selflimiting infections). ${ }^{[1,7]}$ For instance, more than $40 \%$ of the patients with urinary tract infections had used antibiotics inappropriately. ${ }^{[8]}$ Antibiotic consumption is one of the highest among prescribed medicines. ${ }^{[9]}$ They are also widely self-medicated from other sources, including direct purchase from a community pharmacy without a prescription. ${ }^{[12]}$ Despite the law against antibiotic supply without a prescription, they are commonly supplied in LMICs more often inappropriately. ${ }^{[10,11]}$
In the war against AR, pharmacists, known as "drug experts", play an integral role in both community and hospital settings as directing the antibiotic practices toward a right path. The position of hospital pharmacists have flourished in antimicrobial stewardship programs significantly over the past few decades. ${ }^{[12]}$ They are expected to have better knowledge about antibiotic therapy and emerging resistance than community pharmacists due to more exposure to clinical settings and interacting with other health professionals. Besides, community pharmacists, who are considered gateway practitioners, serve typically as patients' first contact in the healthcare seeking chain; therefore, have a role in minimising self-medication with antibiotics in community settings. ${ }^{[13,14]}$ However, inappropriate antibiotic supply is widely observed in LMICs due to several factors including lack of pharmacy and clinical training, pharmacist's knowledge about antibiotics, external pressure from consumers and pharmacy owners, profit motives and poor regulation enforcement. ${ }^{[15,16]}$

Several research have indicated the fact that inadequate knowledge of pharmacy staff about antibiotics, AR, and legal aspects of antibiotic supply contribute to illegal and inappropriate antibiotic dispensing practice in LMICs. ${ }^{[15,17,18]}$ It was also found among final year pharmacy undergraduates among different universities in Sri Lanka that their basic knowledge about effectiveness antibiotics for viral conditions was lacking. ${ }^{[19]}$ However, there are no studies conducted that target the Sri Lankan pharmacists to assess 


\section{Meenu, et al:: Pharmacists' KAP Related to Antibiotics in Sri Lanka}

their knowledge, attitude and practice concerning the usage of antibiotics and their resistance. In Sri Lanka, people who have a certificate (efficiency), diploma (proficiency), or degree in pharmacy can get registered at Sri Lanka Medical Council (SLMC) as a pharmacist and granted equal right to dispense medicine irrespective of their qualification. Most of community pharmacists in Sri Lanka are certificate holders (efficiency pharmacists) and most of the hospital pharmacist are with either diploma or proficiency pharmacy certificate holders. ${ }^{[20]}$ As a result, their depth of knowledge may vary depending on the pharmacy program they have followed.

World Health Organization (WHO) has emphasized the importance of promoting and facilitating global meassures to combat AR and released a global action plan in 2015. ${ }^{[1]}$ Providing appropriate information for healthcare professionals regarding the rational use of antibiotics and improving their awareness of AR are key strategies mentioned in WHO guidelines. ${ }^{[1,22]}$ Looking at pharmacist's roles in combating AR, it is believed that their competence in understanding antibiotic use and resistance paterns and their proactive related attitudes can greatly impact the appropriate use of antibiotic.

Therefore, it is of fundamental importance to understand the KAP of Sri Lankan pharmacists on antibiotics and AR in order to understand antibiotics dispensing practice by pharmacists with various pharmacy qualifications. The aim of the study was to assess the knowledge, attitudes and practices related to antibiotic use among community and hospital pharmacists in Galle District, Sri Lanka.

Accordingly, the objectives of the present study were: (1) to assess the pharmacists' level of knowledge and attitudes related to antibiotic use and resistance, (2) to compare the knowledge, attitudes and practices related to antibiotic use between community and hospital pharmacists; and (3) to assess the socio-demographic factors influencing on their knowledge and attitudes about antibiotics use and AR.

\section{MATERIALS AND METHODS}

Study design and setting: A cross-sectional study was carried out among community and hospital pharmacists at District Galle municipality in Sri Lanka.

Sample size: There are limited numbers of pharmacists practicing in the Hospital and Community settings in the selected study area. Therefore, we hoped to reach all the pharmacists in the study area. According to food and drug inspector, Galle district, there are 50 community pharmacists and according to chief pharmacists at the teaching hospital "Karapitiya and Teaching Hospital Mahamodara" in Galle, Sri Lanka total 50 hospital pharmacists are practicing. Hence, we have set up our sample size to 100.

Inclusion Criteria: The pharmacists who are (1) registered with SLMC and practicing in Sri Lanka as either in a community or hospital setting, (2) able to read and write Sinhala or English and (3) gave written informed consent to participate in the study were included.

Ethical approval: The study was conducted after obtaining ethical approval (Reference No: 31.03.2015.03.10) from the Ethical Review Committee, Faculty of Medicine, University of Ruhuna, Sri Lanka. Written permission also obtained from directors of the respective hospital.

Data collection: The data were collected using a self-administered questionnaire by approaching all the eligible pharmacists $(\mathrm{N}=100)$ by a trained final-year pharmacy student. After explaining the purpose of study and the confidentiality of the data and confirming that every participant well aware about the study, consent was obtained each and every participant. The participation for this study was voluntary. The questionnaire was consisted of 32 questions and it was taken approximately 10-15 mins to complete the questionnaire.

Questionnaire: The study instrument was a self-administered questionnaire. The questionnaire was adopted from previous studies that has already been undergone face validation and content validation process. ${ }^{[23-25]}$ The original questionnaire was prepared in English with slight modifications according Sri Lankan set-up and translated to local Sinhala language by a bilingual expert and was back translated by an independent bilingual expert for the purpose of validation before administering it to pharmacists. The questionnaire consisted of five sections. In section one the respondents were given eight statements to assess their knowledge about antibiotic use and all the statements were True/False type. Section two consisted of five statements aiming to assess the attitudes of the respondents related to antibiotic use. In the section three, the respondents were asked four questions to assess their practices self-reported on dispensing antibiotics without a prescription. If their answer was "yes" for dispensing antibiotics without a prescription, then they were continued to ask questions about the frequency of dispensing, the reason for dispensing and finally the relevant disease conditions they dispensed for. Section four consisted of 10 statements aiming at assessing the possible causes of AR. And the final section was the description of socio-demographic characteristics of the participants.

A series of statements which were intended to study the attitudes of the respondents related to antibiotic use and possible causes of AR were analysed by using a 5 -point Likert scale, whose responses ranged from 'strongly agree' to 'strongly disagree'.

\section{Table 1: The questionnaire structure corresponding to study aim.}

\begin{tabular}{|c|c|c|c|}
\hline Section & Aim & Question & $\begin{array}{l}\text { Type of } \\
\text { questions }\end{array}$ \\
\hline $\begin{array}{l}\text { 1. Knowledge } \\
\text { about antibiotic } \\
\text { use }\end{array}$ & $\begin{array}{l}\text { (1), (2), } \\
(3)\end{array}$ & eight statements & $\begin{array}{l}\text { True/False } \\
\text { question }\end{array}$ \\
\hline $\begin{array}{l}\text { 2. Attitudes related } \\
\text { to antibiotic use }\end{array}$ & $\begin{array}{l}(1),(2), \\
(3)\end{array}$ & five statements & $\begin{array}{l}\text { A 5-point Likert } \\
\text { scale }\end{array}$ \\
\hline $\begin{array}{l}\text { 3. Practices } \\
\text { on dispensing } \\
\text { antibiotics without } \\
\text { a prescription }\end{array}$ & (2) & $\begin{array}{l}\text { the frequency of dispensing, } \\
\text { reason for dispensing } \\
\text { and the relevant disease } \\
\text { conditions }\end{array}$ & $\begin{array}{l}\text { Yes/No question } \\
\text { Multiple choice } \\
\text { questions }\end{array}$ \\
\hline $\begin{array}{l}\text { 4. Knowledge } \\
\text { about the possible } \\
\text { causes of AR }\end{array}$ & (1), (3) & ten statements & $\begin{array}{l}\text { A 5-point Likert } \\
\text { scale }\end{array}$ \\
\hline $\begin{array}{l}\text { 5. Socio- } \\
\text { demographic } \\
\text { characteristics }\end{array}$ & (2), (3) & $\begin{array}{l}\text { age, pharmacy practice } \\
\text { experience year, gender, } \\
\text { pharmacy setting, level of } \\
\text { pharmacy education }\end{array}$ & $\begin{array}{l}\text { Open questions } \\
\text { Multiple choice } \\
\text { questions }\end{array}$ \\
\hline
\end{tabular}

(1) to assess the pharmacists' level of knowledge and attitudes related to antibiotic use and resistance; (2) to compare the knowledge, attitudes and practices related to antibiotic use between community and hospital pharmacists; (3) to assess the socio-demographic factors influencing on their knowledge and attitudes about antibiotics use and antibiotics resistance.

\section{Measures}

1) Knowledge was measured using two sections. The knowledge about antibiotic use section (section 1), one mark was given for each correct answer and zero for each false or don't know response, and these scores were summed to give an overall score (0-8). The knowledge section regarding possible causes of AR (section 4), one mark was given for correct responses which included "strongly agree" and "agree" and zero mark for the wrong 
response which were "strongly disagree", "disagree" and "no opinion". These scores were summed to give a total score (0-10) for overall knowledge related to possible causes AR. The distribution of the two created knowledge score variables were highly skewed so that they were again recoded into two levels by median split as low knowledge and high knowledge which were used as outcome and predictor variables.

2) Attitude related to antibiotic use was assessed using 5 statements (section 2), each of them had 5 response options from strongly agree to strongly disagree. Scores were used from one to five, giving from 1 for "strongly agree" to 5 for "strongly disagree". The reliability of the scale was measured using Cronbach's alpha test. The scores were summed to give a total score (5-25) for overal attitude score (Table 1).

\section{Data Analysis}

The data were analyzed by using SPSS (Version 24.0; IBM Corporation, Somers, NY). Descriptive statistics were performed for socio-demographic variables and main outcome variables. Point estimates such as frequencies, percentages, median and interquartile range were calculated to describe the participants' demographic characteristics, knowledge, attitudes and practices related to antibiotic use and resistance.

Chi-square test was performed to see the association between each of the statement of main outcome variables (related to knowledge about antibiotic use, attitude related to antibiotic use and possible causes of AR) and pharmacy settings (hospital pharmacy and community pharmacy).

Multiple logistic regressions were performed to find the association of participants' demographic characteristics and knowledge on outcome variables. The dependent variables were determined by using section 1 (knowledge about antibiotic use), section 2 (attitudes regarding antibiotic use), and section 4 (possible causes of AR) of the questionnaire.

All the predictors adjusted in the multiple regression models were entered simultaneously to predict the unique contribution of the variables to the outcomes of interest. The predictors adjusted in the models including gender (female $=0 ;$ male $=1$ ), pharmacy practice experience years (continuous), age (continuous, in years), pharmacy setting (hospital pharmacy $=0$; community pharmacy $=1$ ), level of pharmacy education (proficiency pharmacy $=0$, efficiency pharmacy/ B. Pharm = 1), knowledge about antibiotics (score 0-7 low knowledge $=0$, score 8 high knowledge $=1)$, knowledge about AR (score 0-8 low knowledge $=0$, score over 8 high knowledge $=1$ ) were entered into the models. Odds ratios (OR), adjusted odds ratios (Adj. OR) and $95 \%$ confidence intervals $(\mathrm{CI})$ were calculated where appropriate. All $P$-values presented are two tailed and level of significance was set at $P<.05$.

\section{RESULTS}

There was an overall response rate of $90 \%(n=90)$; of the 100 participants were approached; seven community pharmacists and three hospital pharmacists refused their consent to be in the study due to various reasons. The sociodemographic data of the participants are shown in Table 2. Mean age of the respondents was 41 with the standard deviation (SD) of 9.4. The rate of male participants was slightly higher than females $(54.4 \%$ and $45.6 \%$ respectively). All pharmacists were having considerable years of working experience $(\mathrm{Mean}=15$ years and $\mathrm{SD}=9.7)$. Most of the respondents were from hospital pharmacy setting which is accounted around 52\%. Among hospital pharmacists most of them were from outdoor dispensary (38.3\%) and others were $23.4 \%, 31.9 \%$ and $6.4 \%$ from indoor dispensary, main stores, and central reconstitution unit respectively. Almost all the community pharmacists $(88.4 \%$ ) practiced in retail pharmacies. Educational qualifications

\begin{tabular}{|l|l|}
\hline \multicolumn{2}{|l|}{ Table 2: Socio-demographic characteristics of } \\
respondents \\
\hline Variable & Frequency (\%) \\
\hline Age & $\mathrm{N}=90$ \\
Mean (SD) & $41(9.4)$ \\
Gender & $\mathrm{N}=90$ \\
Male & $49(54.4)$ \\
Female & $41(45.6)$ \\
& \\
Pharmacy practice experience (years) & $\mathrm{N}=90$ \\
Mean (SD) & $15(9.7)$ \\
& \\
Pharmacy setting & $\mathrm{N}=90$ \\
Hospital pharmacy & $47(52.2)$ \\
Community pharmacy & $43(47.8)$ \\
& \\
Hospital pharmacy setting & $\mathrm{N}=47$ \\
Outdoor & $18(38.3)$ \\
Indoor & $11(23.4)$ \\
Main stores & $15(31.9)$ \\
Central reconstitution unit & $3(6.4)$ \\
Community pharmacy setting & $\mathrm{N}=43$ \\
Retail & $38(88.4)$ \\
Wholesale & $1(2.3)$ \\
Retail \& Wholesale & $4(9.3)$ \\
Level of pharmacy education & $\mathrm{N}=90$ \\
Efficiency pharmacy & $43(47.8)$ \\
Proficiency pharmacy & $45(50.0)$ \\
B.Pharm & $2(2.2)$ \\
\hline N = total number of respondents $\quad \mathrm{SD}=$ standard deviation \\
\hline
\end{tabular}

of participants were efficiency pharmacy $(47.8 \%)$, proficiency pharmacy $(45 \%)$ and only $2.2 \%$ of them were graduate pharmacists with B.Pharm degree. Almost all the hospital pharmacists were qualified as proficiency in pharmacy $(96 \%)$ while only $4 \%$ of them were with the B.Pharm degree. Meanwhile, all the community pharmacists were qualified as efficiency in pharmacy $(100 \%)$.

\section{Knowledge related to antibiotic use}

(Table 3) describes the descriptive statistics of knowledge related to antibiotic use among hospital and community pharmacists. The results reveal a good knowledge about antibiotic use (Median $=7.00$, range: $2.00-8.00$, IQR= 7.00-8.00). The median knowledge score of hospital pharmacists (median= 8.00 , range: $5.00-8.00, \mathrm{IQR}=7.00-8.00)$ is not significantly higher than community pharmacists (median $=7.00$, range: $2.00-8.00, \mathrm{IQR}=6.00-8.00$ ) $(P=0.052)$. It can be seen that more than $90 \%$ of respondents were having good knowledge for almost all the questions related to antibiotic use except the statements "bacteria are not causing common cold and flu" ( $\mathrm{n}=76$, $84.4 \%$ ) and "diphenhydramine is not an antibiotic" which was the variable responded correctly by the least number of participants ( $n=54,60.0 \%)$. The proportion of hospital pharmacists giving correct responses is significantly higher than community pharmacists in two knowledge items "inappropriate antibiotic use can lead to ineffective treatment" (100\% and $91 \%$ respectively, $P=0.048)$ and "inappropriate antibiotic use increases emergence of bacterial resistance" (100\% and 86\% respectively, $P=0.010)$.

\section{Knowledge related to possible causes AR}

Table 4 presents the knowledge related to possible causes of AR among hospital and community pharmacists. The results reveal an overall good knowledge about possible causes of $\mathrm{AR}$ (Median $=8.00$, range: $0.0-10.0$, $\mathrm{IQR}=6.0-9.0)$. The median knowledge score of hospital pharmacists 


\begin{tabular}{|c|c|c|c|c|}
\hline Variable & $\begin{array}{l}\text { Frequency } \\
(\%)\end{array}$ & $\begin{array}{l}\text { Community } \\
\text { Pharmacists } \\
\text { Frequency (\%) }\end{array}$ & $\begin{array}{l}\text { Hospital } \\
\text { Pharmacists } \\
\text { Frequency (\%) }\end{array}$ & $\begin{array}{l}\text { Chi-square } \\
\text { P value }\end{array}$ \\
\hline $\begin{array}{l}\text { Inappropriate antibiotic use can lead to ineffective treatment } \\
\text { True }\end{array}$ & $\begin{array}{l}N=90 \\
86(95.6)\end{array}$ & $\begin{array}{l}N=43 \\
39(90.7)\end{array}$ & $\begin{array}{l}N=47 \\
47(100.0)\end{array}$ & $0.048^{*}$ \\
\hline $\begin{array}{l}\text { Inappropriate antibiotic use increases adverse effects } \\
\text { True }\end{array}$ & $\begin{array}{l}N=90 \\
89(98.9)\end{array}$ & $\begin{array}{l}N=43 \\
42(97.7)\end{array}$ & $\begin{array}{l}N=47 \\
47(100.0)\end{array}$ & $0.478^{*}$ \\
\hline $\begin{array}{l}\text { Inappropriate antibiotic use increases emergence of bacterial resistance } \\
\text { True }\end{array}$ & $\begin{array}{l}N=90 \\
84(93.3)\end{array}$ & $\begin{array}{l}N=43 \\
37(86.0)\end{array}$ & $\begin{array}{l}N=47 \\
47(100.0)\end{array}$ & $0.010^{*}$ \\
\hline $\begin{array}{l}\text { Inappropriate antibiotics use gives additional burden of medical cost } \\
\text { True }\end{array}$ & $\begin{array}{l}N=90 \\
84(93.3)\end{array}$ & $\begin{array}{l}\mathrm{N}=43 \\
38(88.4)\end{array}$ & $\begin{array}{l}N=47 \\
46(97.9)\end{array}$ & $0.100^{*}$ \\
\hline $\begin{array}{l}\text { If taken too often antibiotics are less likely to work in future } \\
\text { True }\end{array}$ & $\begin{array}{l}N=90 \\
86(95.6)\end{array}$ & $\begin{array}{l}N=43 \\
40(93.0)\end{array}$ & $\begin{array}{l}\mathrm{N}=47 \\
46(97.9)\end{array}$ & $0.345^{*}$ \\
\hline $\begin{array}{l}\text { Bacteria are not causing common cold \& flu } \\
\text { True }\end{array}$ & $\begin{array}{l}N=90 \\
76(84.4)\end{array}$ & $\begin{array}{l}N=43 \\
36(83.7)\end{array}$ & $\begin{array}{l}N=47 \\
40(85.1)\end{array}$ & 1.000 \\
\hline $\begin{array}{l}\text { Diphenhydramine is not an antibiotic } \\
\text { True }\end{array}$ & $\begin{array}{l}N=90 \\
54(60.0)\end{array}$ & $\begin{array}{l}N=43 \\
23(53.5)\end{array}$ & $\begin{array}{l}N=47 \\
31(66.0)\end{array}$ & 0.283 \\
\hline $\begin{array}{l}\text { AR is a serious public health issue } \\
\text { True }\end{array}$ & $\begin{array}{l}N=90 \\
82(91.1)\end{array}$ & $\begin{array}{l}N=43 \\
37(86.0)\end{array}$ & $\begin{array}{l}N=47 \\
45(95.7)\end{array}$ & 0.145 \\
\hline $\begin{array}{l}\text { Overall knowledge } \\
\text { Median [IQR] }\end{array}$ & $\begin{array}{l}N=90 \\
7.0[7.08 .0]\end{array}$ & $\begin{array}{l}\mathrm{N}=43 \\
7.0[6.0-8.0]\end{array}$ & $\begin{array}{l}N=47 \\
8.0[7.0-8.0]\end{array}$ & $0.052 \dagger$ \\
\hline
\end{tabular}

(Median= 9.0, range: $2.0-10.0, \mathrm{IQR}=7.0-10.0)$ was not significantly higher than community pharmacists (Median $=7.0$, range: $0.00-10.0, \mathrm{IQR}=5.0-9.0$ ) $(P=0.076)$. It was found that the overall highest correct response was "use of antibiotics for longer than standard duration causes AR" ( $n=76,84.4 \%)$. However, overall lower percentages of pharmacists agreed with following causes of AR; "lack of restriction on antibiotic usage can cause AR" ( $n=60$, 66.7\%), "excessive antibiotic use in live-stock (Animals reared for food) causes AR" ( $n=59,65.6 \%)$ and "poor infection control measures cause AR" $(n=53,58.9 \%)$. Hospital pharmacists had significantly higher knowledge for the statements such as "use of antibiotics for self-limited non bacterial infections" ( $92 \%$ and $74 \%$ respectively, $P=0.030$ ), "use of antibiotics with a broader than necessary spectrum" ( $87 \%$ and $70 \%$ respectively, $P=0.043)$, and "mutational and evolutionary changes in the microorganisms" ( $83 \%$ and $67 \%$ respectively, $P=0.003$ ) than the community pharmacists.

\section{Attitudes related to antibiotic use}

Table 5 illustrates the descriptive statistics of attitudes related to antibiotic use among hospital and community pharmacists. Overall, more than $84 \%$ of respondents were having positive responses on all five attitudes related statements. All the respondents $(100 \%)$ were having positive attitudes with the statement "antibiotics are not safe drugs and cannot be commonly used". There was no significant difference found between hospital and community pharmacists on attitude-related statements.

\section{Practices related to antibiotic use}

Almost all the respondents $(n=88,98 \%)$ claimed that they had not dispensed antibiotics without a prescription. Only about $2 \%(n=2)$ of them had dispensed antibiotics without a prescription occasionally. The reasons which caused to dispense antibiotics without a prescription were high treatment costs $(n=1)$, having previous experiences with the disease condition $(n=1)$ and knowing about the drug and disease $(n=1)$. The common disease conditions reported were fever $(n=1)$, diarrhea $(n=2)$, wound infections $(n=2)$ and eye or ear infections $(n=1)$.

Association of socio-demographic characteristics with knowledge related to antibiotic use and resistance, and attitudes

As Table 6 describes the pharmacists whose knowledge about antibiotic use was high are more likely to have high knowledge about possible causes of AR (Adj. OR $=3.94 ; 95 \%$ CI: $1.57-9.88 ; P=0.003$ ) and vice versa. The socio-demographic factors did not have any impact on the regarding knowledge, except gender. Males were less likely to have high level of knowledge related to AR (Adj. OR $=0.36$; 95\% CI: $0.14-0.91 ; P=0.03$ ). Hence, the knowledge about antibiotic use increased the likelihood of having positive attitude toward antibiotic use (Adj. OR $=3.71$; 95\% CI: $1.54-8.92 ; P=0.003)$.

\section{DISCUSSION}

This study assessed the knowledge, attitude and practice related to antibiotic use and resistance among community and hospital pharmacists in Galle District, Sri Lanka. To the best of our knowledge and literature evidence this is the first ever study conducted to assess the KAP related to antibiotics among both community and hospital pharmacists in Sri Lanka. The overall response rate was $90 \%$ indicating the strength of the study.

Both hospital and community pharmacists were having comparatively high knowledge about antibiotic use and these findings are comparable with other studies conducted among senior healthcare students. ${ }^{[23,24,26]}$ However, about $16 \%$ of the pharmacists wrongly responded that bacteria are causing common cold and flu, which are viral infections that antibiotics could not work for. As a pharmacist, it is crucial to know that antibiotics are only effective against bacterial infections but more importantly, to identify which conditions are not caused by bacteria. There were other studies showing a bigger knowledge 
Meenu, et al.: Pharmacists' KAP Related to Antibiotics in Sri Lanka

\begin{tabular}{|c|c|c|c|c|}
\hline Variable & Frequency (\%) & $\begin{array}{l}\text { Community } \\
\text { Pharmacists } \\
\text { Frequency (\%) }\end{array}$ & $\begin{array}{l}\text { Hospital } \\
\text { Pharmacists } \\
\text { Frequency (\%) }\end{array}$ & Chi-square $P$ value \\
\hline $\begin{array}{l}\text { Use of antibiotics for self-limited non bacterial infections } \\
\text { Agree } \\
\text { Disagree }\end{array}$ & $\begin{array}{l}\mathrm{N}=90 \\
75(83.3) \\
15(16.7)\end{array}$ & $\begin{array}{l}\mathrm{N}=43 \\
32(74.4) \\
11(25.6)\end{array}$ & $\begin{array}{l}\mathrm{N}=47 \\
43(91.5) \\
4(8.5)\end{array}$ & 0.030 \\
\hline $\begin{array}{l}\text { Use of antibiotics with a broader than necessary spectrum } \\
\text { Agree } \\
\text { Disagree }\end{array}$ & $\begin{array}{l}N=90 \\
71(78.9) \\
19(21.1)\end{array}$ & $\begin{array}{l}N=43 \\
30(69.8) \\
13(30.2)\end{array}$ & $\begin{array}{l}N=47 \\
41(87.2) \\
6(12.8)\end{array}$ & 0.043 \\
\hline $\begin{array}{l}\text { Use of antibiotics for shorter than standard duration } \\
\text { Agree } \\
\text { Disagree }\end{array}$ & $\begin{array}{l}N=90 \\
68(75.6) \\
22(24.4)\end{array}$ & $\begin{array}{l}N=43 \\
29(67.4) \\
14(32.6)\end{array}$ & $\begin{array}{l}N=47 \\
39(83) \\
8(17)\end{array}$ & 0.087 \\
\hline $\begin{array}{l}\text { Poor infection control measures } \\
\text { Agree } \\
\text { Disagree }\end{array}$ & $\begin{array}{l}N=90 \\
53(58.9) \\
37(41.1)\end{array}$ & $\begin{array}{l}N=43 \\
22(51.2) \\
21(48.8)\end{array}$ & $\begin{array}{l}N=47 \\
31(66) \\
16(34)\end{array}$ & 0.154 \\
\hline $\begin{array}{l}\text { Use of antibiotics for self-limited bacterial infections } \\
\text { Agree } \\
\text { Disagree }\end{array}$ & $\begin{array}{l}N=90 \\
66(73.3) \\
24(26.7)\end{array}$ & $\begin{array}{l}N=43 \\
28(65.1) \\
15(34.9)\end{array}$ & $\begin{array}{l}N=47 \\
38(80.9) \\
9(19.1)\end{array}$ & 0.092 \\
\hline $\begin{array}{l}\text { Empirical antibiotic therapy } \\
\text { Agree } \\
\text { Disagree }\end{array}$ & $\begin{array}{l}N=90 \\
69(76.7) \\
21(23.3)\end{array}$ & $\begin{array}{l}N=43 \\
33(76.7) \\
10(23.3)\end{array}$ & $\begin{array}{l}N=47 \\
36(76.6) \\
11(23.4)\end{array}$ & 0.987 \\
\hline $\begin{array}{l}\text { Mutational \& evolutionary changes in the microorganisms } \\
\text { Agree } \\
\text { Disagree }\end{array}$ & $\begin{array}{l}N=90 \\
74(82.2) \\
16(17.8)\end{array}$ & $\begin{array}{l}N=43 \\
30(69.8) \\
13(30.2)\end{array}$ & $\begin{array}{l}N=47 \\
44(93.6) \\
3(6.4)\end{array}$ & 0.003 \\
\hline $\begin{array}{l}\text { Lack of restrictions on antibiotic usage } \\
\text { Agree } \\
\text { Disagree }\end{array}$ & $\begin{array}{l}N=90 \\
60(66.7) \\
30(33.3)\end{array}$ & $\begin{array}{l}N=43 \\
27(62.8) \\
16(37.2)\end{array}$ & $\begin{array}{l}N=47 \\
33(70.2) \\
14(29.8)\end{array}$ & 0.456 \\
\hline $\begin{array}{l}\text { Excessive antibiotic use in live-stock } \\
\text { Agree } \\
\text { Disagree }\end{array}$ & $\begin{array}{l}N=90 \\
59(65.6) \\
31(34.4)\end{array}$ & $\begin{array}{l}N=43 \\
28(65.1) \\
15(34.9)\end{array}$ & $\begin{array}{l}N=47 \\
31(66) \\
16(34)\end{array}$ & 0.933 \\
\hline $\begin{array}{l}\text { Use of antibiotics for longer than standard duration } \\
\text { Agree } \\
\text { Disagree }\end{array}$ & $\begin{array}{l}N=90 \\
76(84.4) \\
14(15.6)\end{array}$ & $\begin{array}{l}N=43 \\
35(81.4) \\
8(18.6)\end{array}$ & $\begin{array}{l}N=47 \\
41(87.2) \\
6(12.8)\end{array}$ & 0.445 \\
\hline $\begin{array}{l}\text { Overall knowledge } \\
\text { Median [IQR] }\end{array}$ & $\begin{array}{l}N=90 \\
8.0[6.0-9.0]\end{array}$ & $\begin{array}{l}N=43 \\
7.0[5.0-9.0]\end{array}$ & $\begin{array}{l}N=47 \\
9.00[7.0-10.0]\end{array}$ & $0.076+$ \\
\hline
\end{tabular}

\begin{tabular}{|c|c|c|c|c|}
\hline Variable & $\begin{array}{l}\text { Frequency } \\
\text { (\%) }\end{array}$ & $\begin{array}{l}\text { Community } \\
\text { Pharmacists } \\
\text { Frequency (\%) }\end{array}$ & $\begin{array}{l}\text { Hospital } \\
\text { Pharmacists } \\
\text { Frequency (\%) }\end{array}$ & $\begin{array}{l}P \\
\text { value }\end{array}$ \\
\hline $\begin{array}{l}\text { Antibiotics should not be dispensed for common cold on patient demand } \\
\text { Agree } \\
\text { Disagree }\end{array}$ & $\begin{array}{l}N=90 \\
82(91.1) \\
8(8.9)\end{array}$ & $\begin{array}{l}N=43 \\
39(90.7) \\
4(9.3)\end{array}$ & $\begin{array}{l}N=47 \\
43(91.5) \\
4(8.5)\end{array}$ & $1.000^{*}$ \\
\hline $\begin{array}{l}\text { Antibiotics should not be dispensed for fever on patient demand } \\
\text { Agree } \\
\text { Disagree }\end{array}$ & $\begin{array}{l}N=90 \\
89(98.9) \\
1(1.1)\end{array}$ & $\begin{array}{l}N=43 \\
42(97.7) \\
1(2.3)\end{array}$ & $\begin{array}{l}N=47 \\
47(100) \\
0\end{array}$ & $0.478^{*}$ \\
\hline $\begin{array}{l}\text { The course of antibiotic should be continued even if patient feels better } \\
\text { Agree } \\
\text { Disagree }\end{array}$ & $\begin{array}{l}N=90 \\
89(98.9) \\
1(1.1)\end{array}$ & $\begin{array}{l}\mathrm{N}=43 \\
42(97.7) \\
1(2.3)\end{array}$ & $\begin{array}{l}N=47 \\
47(100) \\
0\end{array}$ & $0.478^{*}$ \\
\hline $\begin{array}{l}\text { Skipping doses contributes to AR } \\
\text { Agree } \\
\text { Disagree }\end{array}$ & $\begin{array}{l}N=90 \\
76(84.4) \\
14(15.6)\end{array}$ & $\begin{array}{l}N=43 \\
33(76.7) \\
10(23.3)\end{array}$ & $\begin{array}{l}N=47 \\
43(91.5) \\
4(8.5)\end{array}$ & 0.054 \\
\hline $\begin{array}{l}\text { Antibiotics are not safe drugs \& cannot be commonly used } \\
\text { Agree } \\
\text { Disagree }\end{array}$ & $\begin{array}{l}N=90 \\
90(100) \\
0\end{array}$ & $\begin{array}{l}N=43 \\
43(100) \\
0\end{array}$ & $\begin{array}{l}N=47 \\
47(100) \\
0\end{array}$ & \\
\hline $\begin{array}{l}\text { Overall attitudes } \\
\text { Median [IQR] }\end{array}$ & $\begin{array}{l}N=90 \\
5.0[4.7-5.0]\end{array}$ & $\begin{array}{l}N=43 \\
5.00[4.0-5.0]\end{array}$ & $\begin{array}{l}N=47 \\
5.0[5.0-5.0]\end{array}$ & \\
\hline
\end{tabular}




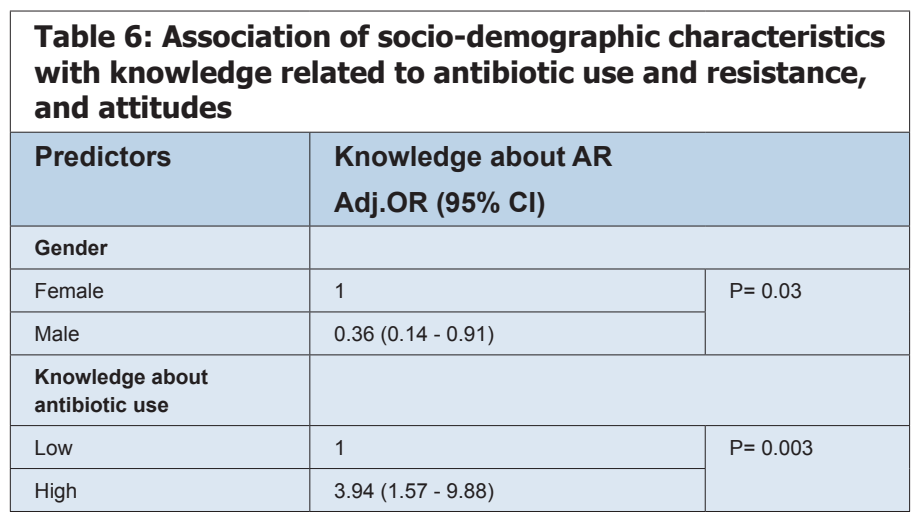

\begin{tabular}{|l|l|l|}
\hline Predictors & $\begin{array}{l}\text { Knowledge about antibiotic use } \\
\text { Adj.OR } \mathbf{( 9 5 \%} \mathbf{~ C l})\end{array}$ \\
\hline Knowledge about AR & \multicolumn{2}{|l|}{$\mathrm{P}=0.005$} \\
\hline Low & 1 & \\
\hline High & $3.53(1.47-8.49)$ & \\
\hline
\end{tabular}

\begin{tabular}{|l|l|l|}
\hline Predictors & $\begin{array}{l}\text { Attitude related to antibiotic use Adj.OR } \\
(\mathbf{9 5 \%} \mathbf{C l})\end{array}$ \\
\hline $\begin{array}{l}\text { Knowledge about } \\
\text { antibiotic use }\end{array}$ & \multicolumn{2}{|l|}{$\mathrm{P}=0.003$} \\
\hline Low & 1 & \\
\hline High & $3.71(1.54-8.92)$ & \\
\hline
\end{tabular}

gap about the effectiveness of antibiotics among pharmacy students ${ }^{[26]}$ and the public. ${ }^{[27]}$ In the context of inappropriate antibiotic use for common viral infections which is problematic practice contributing to $\mathrm{AR},{ }^{[28]}$ there is a need for educational intervention for pharmacists not only to reduce irrational antibiotic supply, but also to ensure they could disseminate the message to the pharmacy trainees and the public. Additionally, poor knowledge on differentiating antibiotics from anti-histamine (45\%) was reflected in this study. Anti-histamines, which are one of the symptom-relief medicines, are frequently used in common cold and flu. ${ }^{[2]}$ Therefore, the confusion between these two types of medicine could worsen the irrational supply of antibiotics and this should be addressed seriously. The results were more discouraging when recent studies also found inadequate knowledge among pharmacists about antibiotic definition ${ }^{[17]}$ and characteristics. ${ }^{[30]}$ These mentioned gaps in knowledge could be bridged by outcome-based educational strategies and promoting rational antibiotic use.

The study depicted overall good knowledge about potential contributors of AR among pharmacists surveyed which is in line with other studies. ${ }^{[26,31]}$ The predominant percentage of them were aware that prolonged use of antibiotic could accelerate AR (84\%). However, pharmacists placed little weight on the role of lack of restriction on antibiotic usage (33\%). This result was in accordance to the current situation where illegal non-prescription supply of antibiotic was commonly found in Sri Lanka. To reduce resistant strains caused by this, stricter regulations may need to be introduced. Moreover, more pharmacists did not consider that excessive antibiotic use in live-stock $(34 \%)$ and poor infection control measures ( $41 \%$ ) could contribute to AR. It could be explained that pharmacists were less concerned about antibiotic use in agriculture and infection control as they were less exposed to those topics.

Hospital pharmacists were found to have greater knowledge about some consequences of inappropriate antibiotic use and some possible causes of AR than that of community pharmacists and the findings were consistent with their respective pharmacy education as well. In Sri Lanka, the hospital pharmacists who are granted the "Certificate of Proficiency in Pharmacy" are internal pharmacists with two years of academic education followed by 6 months practical experience in hospital pharmacy. Whereas, the community pharmacists who receive the "Certificate of Efficiency in Pharmacy" are external pharmacists with only two-year apprenticeship under registered pharmacist in a registered pharmacy premises. ${ }^{[20,32]}$ With a more advanced degree, compared to community pharmacists, hospital pharmacists have greater opportunities to attend workshops, seminars related rational usage of medicines. ${ }^{[33]}$ A minimum number of $\mathrm{B}$. Pharm holders (2.2\%) were practicing in the hospital setting because it is a recently commenced degree programme in Sri Lanka and even from those; majority is practicing in the industrial or academic field rather than hospital and community setting. Similar results found in a recent study conducted in Brazil that pharmacists who work in hospital settings have an increased awareness about AR, which could be explained by more exposure to severe patients with resistant bacteria. ${ }^{[34]}$ The results in our study could provide an opportunity to talor effective strategies to bring an appropriate change in both two populations.

The study findings also illustrated that pharmacists who were knowledgeable about antibiotic use will be more likely to have better knowledge about possible causes of AR and vice versa. It could be reasonable because AR are one of the antibiotic use's consequences. Therefore, interventions to increase pharmacist's knowledge about antibiotic use may result in better understandings of AR. Besides, the socio-demographic factors did not have any impact on the regarding knowledge, except gender. Males were less likely to have high level of knowledge related to AR. This result is poor in accordance with other studies in which no difference in terms of gender and level of understanding was shown.

A majority of respondents was having positive responses on all five attitudes-related statements. There was no significant difference found between hospital and community pharmacists on attitude-related statements. Knowledge about antibitoic use increased the likelihood of having positive attitude regarding antibiotic use. This result was noteworthy because it highlighted the fact that educational interventions could have an impact on pharmacist's attitude by increasing their knowledge in this topic.

Almost all the pharmacists (98\%) claimed that they were not dispensing antibiotics without a prescription. These might be overestimated responses because this figure was based on community pharmacists' self-reported data. According to Sri Lankan, legislation antibiotics are prescription-only medicines, therefore, pharmacists may have frightened to say about their actual antibiotic dispensing practice to the researchers. Hence, this finding was possibly affected by social desirability bias. Many studies conducted elsewhere have found that it is possible to buy antibiotics directly from community pharmacies without a prescription. ${ }^{[35-38]}$ Additionally, studies conducted elsewhere, in north Spain and India, found that knowledge and attitudes of the pharmacists were strongly associated with dispensing antibiotics without a prescription. ${ }^{[39,40]}$

Some limitations can be noticed in our study like most surveys. One limitation is that the project approached only one district in Sri Lanka. There should be broader studies covering all the other districts may reflect better understanding of Sri Lankan pharmacists' KAP related to antibiotics. However, we managed to cover the entire practicing pharmacists with different qualifications in that particular area and setting which can be similar to all the districts in Sri Lanka. Additionally, self-reporting about antibiotic dispensing practice may face the social desirability bias as their practice is under-reported. Therefore, it is highly recommended to conduct a simulated patient study in the future to understand the actual antibiotic dispensing 
practice among community pharmacists in Sri Lanka.

\section{CONCLUSION}

The level of pharmacy education has an impact on the knowledge regarding antibiotic use, resistance to some extent. Knowledge related to antibiotic use has a positive impact on knowledge of antibiotic resitance and attitude towards antibiotic use. There is an urgent need of educational interventions to improve the knowledge, attitudes and practices of pharmacists related to antibiotic use and resistance targeting both community and hospital pharmacists. Enforcement of regulations especially regarding antibiotics dispensing should be strengthen in the country and the basic qualification to be a pharmacist should be revised in order to have higher quality pharmacy services in Sri Lanka. Regarding antibiotic supply, self-reported survey revealed that community pharmacists did not dispense antibiotics without a prescription in spite of actual practice. Further studies should be encouraged to determine KAP of Pharmacists Island wide. Simulated patient studies may be ideal method to determine the actual dispensing practice of antibiotics in the community settings.

\section{ACKNOWLEDGEMENT}

We would like to thank all the participants of the survey for their valuable time and effort.

\section{CONFLICT OF INTEREST}

There were no conflicts of interest for the study.

\section{ABBREVIATIONS}

AR: Antibiotic resistance; LMICs: Low and middle-income countries; SLMC: Sri Lanka Medical Council; WHO: World Health Organization; OR: Odds ratio; Adj. OR: Adjusted odds ratio; CI: Confidence intervals; B.Pharm: Bachelor of Pharmacy.

\section{REFERENCES}

1. World Health Organization. The evolving threat of antimicrobial resistance: Options for action. World Health Organization: Geneva; 2012.

2. Jordi V, Tibor P. Update on Antibacterial Resistance in Low-Income Countries: Factors Favoring the Emergence of Resistance. Open Infect Dis J. 2010;4(1):14.

3. Senadheera GP, et al. Resistance and utilization pattern of antibacterial agents in outpatient settings in two Teaching Hospitals in Colombo. Ceylon Med J. 2016;61(3):113-7.

4. Song $\mathrm{JH}$, et al. High prevalence of antimicrobial resistance among clinical Streptococcus pneumoniae isolates in Asia (an ANSORP study). Antimicrob Agents Chemother. 2004;48(6):2101-7.

5. Awad Al, Aboud EA. Knowledge, Attitude and Practice towards Antibiotic Use among the Public in Kuwait. PLoS One. 2015;10(2):e0117910.

6. World Health Organization. Global Strategy for Containment of Antimicrobial Resistance. World Health Organization. 2001.

7. Laxminarayan $\mathrm{R}$, et al. Antibiotic resistance-the need for global solutions. Lancet Infect Dis. 2013;13(12):1057-98.

8. Liu YC, et al. Inappropriate use of antibiotics and the risk for delayed admission and masked diagnosis of infectious diseases: A lesson from Taiwan. Arch Intern Med. 2001;161(19):2366-70.

9. Col NF, O'Connor RW. Estimating worldwide current antibiotic usage: Report of Task Force 1. Rev Infect Dis. 1987;9(3):S232-43.

10. Ocan $\mathrm{M}$, et al. Household antimicrobial self-medication: A systematic review and meta-analysis of the burden, risk factors and outcomes in developing countries. BMC Public Health. 2015;15(1):742.

11. Alhomoud F, et al. Self-medication and self-prescription with antibiotics in the Middle East-do they really happen? A systematic review of the prevalence, possible reasons and outcomes. Int J Infect Dis. 2017;57:3-12.

12. Pollack LA, Srinivasan A. Core elements of hospital antibiotic stewardship programs from the Centers for Disease Control and Prevention. Clin Infect Dis. 2014;59(3):S97-100.

13. Toussaint MDK, Gallagher JC. The Pharmacist's Role in Preventing Antibiotic Resistance. U.S. Pharmacist; 2011;36.

14. Smith F. The quality of private pharmacy services in low and middle-income countries: A systematic review. Pharm World Sci. 2009;31(3):351-61.

15. Miller R, Goodman C. Performance of retail pharmacies in low- and middle-income Asian settings: A systematic review. Health Policy Plan. 2016;31(7):940-53.

16. Roque $\mathrm{F}$, et al. Attitudes of community pharmacists to antibiotic dispensing and microbial resistance: A qualitative study in Portugal. Int J Clin Pharm. 2013;35(3):417-24.

17. Barker AK, et al. What drives inappropriate antibiotic dispensing? A mixedmethods study of pharmacy employee perspectives in Haryana, India. BMJ Open. 2017;7(3):e013190.

18. Hadi MA, et al. Community pharmacists' knowledge, attitude and practices towards dispensing antibiotics without prescription (DAwP): A cross-sectional survey in Makkah Province, Saudi Arabia. Int J Infect Dis. 2016; 47:95-100.

19. Shukry Z, Chathurangani H, Hana M. Assessing knowledge, perception and attitudes about antibiotics among final year pharmacy undergraduates in Sri Lanka. Int J Pharm Pharm. 2017;9(10).

20. Zawahir S, Niyangoda D, Lakmali N, Pharmacy Practice in Developing countries. Achievements and Challenges in Pharmacy Practice in Developing countries. Acievements and Challenges, Elsevier. 2016;475.

21. Mendelson M, Matsoso MP. The World Health Organization Global Action Plan for antimicrobial resistance. S Afr Med J. 2015;105(5):325.

22. Leung $\mathrm{E}$, et al. The WHO policy package to combat antimicrobial resistance. Bull World Health Organ. 2011;89(5):390-2.

23. Akbari N, Prudhivi R, Naidu S. Rational use of Antibiotics and Monitoring of Drug Interactions in Patients with Respiratory Tract Infection. J Pharm Pract Community Med. 2018;4(4):211-5.

24. Khan AKA, Banu GK. Antibiotic Resistance and Usage-A Survey on the Knowledge, Attitude, Perceptions and Practices among the Medical Students of a Southern Indian Teaching Hospital. J Clin Diagn Res. 2013;7(8):1613-6.

25. Jamshed $S Q$, et al. Understanding of antibiotic use and resistance among final-year pharmacy and medical students: A pilot study. J Infect Dev Ctries. 2014;8(6):780-5.

26. Rajiah K, Ren WS, Jamshed SQ. Evaluation of the understanding of antibiotic resistance among Malaysian pharmacy students at public universities: An exploratory study. J Infect Public Health. 2015;8(3):266-73.

27. Shehadeh $\mathrm{M}$, et al. Knowledge, attitudes and behavior regarding antibiotics use and misuse among adults in the community of Jordan: A pilot study. Saudi Pharm J. 2011;20(2):125-33.

28. Huttner B, et al. Characteristics and outcomes of public campaigns aimed at improving the use of antibiotics in outpatients in high-income countries. Lancet Infect Dis. 2010;10(1):17-31.

29. DeSutter Al, Saraswat A, VanDriel ML. Antihistamines for the common cold. Cochrane Database Syst Rev. 2015;(11):CD009345.

30. Yakimova Y. Pharmacists' knowledge of the safety of antibiotics for systemic use. Int J Risk Saf Med. 2015;27(Suppl 1):S11-2.

31. Ahmad A, et al. Knowledge, attitude and practice of B.Sc. Pharmacy students about antibiotics in Trinidad and Tobago. J Res Pharm Pract. 2015;4(1):37-41.

32. Sri Lanka Medical Council, Pharmacology courses in Sri Lanka. 2011.

33. Kheir $\mathrm{N}$, et al. Pharmacy education and practice in 13 Middle Eastern countries. Am J Pharm Educ. 2008;72(6):133.

34. Fiol FDS, et al. Assessment of Brazilian pharmacists' knowledge about antimicrobial resistance. J Infect Dev Ctries. 2015;9(3):239-43.

35. Llor C, Cots JM. The sale of antibiotics without prescription in pharmacies in Catalonia, Spain. Clin Infect Dis. 2009;48(10):1345-9.

36. Plachouras D, et al. Dispensing of antibiotics without prescription in Greece, 2008 : Another link in the antibiotic resistance chain. Euro Surveill. 2010;15(7):19488.

37. Llor C, Monnet DL, Cots JM. Small pharmacies are more likely to dispense antibiotics without a medical prescription than large pharmacies in Catalonia, Spain. Euro Surveill. 2010;15(32):19635.

38. Alabidm AHM, Ibrahim MI, Hassali MA. Dispensing Practices of General practitioners and and Community Pharmacists in Malaysia. J Pharm Pract Res. 
Meenu, et al.: Pharmacists' KAP Related to Antibiotics in Sri Lanka

2013;43(3):187-9.

39. Zapata-Cachafeiro $M$, et al. Determinants of antibiotic dispensing without a medical prescription: A cross-sectional study in the north of Spain. J Antimicrob
Chemother. 2014;69(11):3156-60.

40. Kotwani A, et al. Irrational use of antibiotics and role of the pharmacist: An insight from a qualitative study in New Delhi, India. J Clin Pharm Ther. 2012;37(3):308-12.

Cite this article as: Meenu A, Ha NV, Zawahir S. Knowledge, Attitudes and Practices Related to Antibiotic use among Community and Hospital Pharmacists in District Galle, Sri Lanka. J Pharm Pract Community Med. 2021;7(1):1-8. 